\title{
APPLICATION OF 'SAY YES OR NO’ GAME IN INSTILLING CHARACTER EDUCATION IN EARLY CHILDHOOD
}

\author{
Samsiah $^{\mathrm{a}}$, Rapi Us Djuko \\ ${ }^{a}$ State University of Gorontalo
}

\begin{abstract}
Cosby S. Roger and Janet K Sawyers (1995) Playing is one of fun children's world activities. It can raise children's intrinsic motivation, provide serenity and life balance for them. Instilling education for early age children, particularly for character education is noteworthy, Lickona (1991) states that character is correlated with moral knowing, moral feeling and moral behavior. One of Game 'say yes or no' activities in Early Childhood Character Education is an activity which is expected to be able to instill character education and to make children to be brave in expressing their feeling honestly as well as to stimulate other dimensions of children's development such as value of moral religion, cognitive development, language development, physical motor development, social emotion development, art development and other development. This paper is a literature review about application of 'say yes or no' Game in instilling Character Education at Early Age Children as one of pedagogical approaches for stimulating children's development
\end{abstract}

Keywords: game, playing, early childhood, character education

\section{INTRODUCTION}

In Indonesian National Education Law number 20 year 2003 regarding National Education System stadium that is the development of education and development And body so that ladder more information (article 1 verse 14). Patmonodewo [1]. The definition of early childhood, according to the NAEYC (The National Association for the Education of Young Children) is a child from birth up tp eight years old.

Alwasilah in Khristianto [2] declares that "Precollege education is mainly designed for character building, while collage education is for profession bilding.it means the education we prepare for the child to the adolescent is to out the good characters of humanity in them, it is a very long process with various setting of education, given either formally in the education institution or informally in the social institution, like family, peer interaction, and society as a whole. Concerning to the matter we discuss here, the early childhood character building starts as their body and their brain are ready to play.

Children world is playing world. But in real life these are lots of uneducated games and even dangerous for the children. The children tend to have bad behavior, they don't have good character because sometimes they copy figure in the game.
Based on the reality, the writer tries to make a library Application of 'say yes or no' Game in Instilling Character Education in Early Childhood.

\section{REVIEW OF RELATED LITERATURE}

Rifa Suci Wulandari \& Hestri Hurustyanti [3] (STKIP PGRI Ponorogo) "Character Building of early childhood can be optimalize through the function of traditional game base on local culture" The research result at TK Pancasila showed that the stages of traditional games application included: (1) Planning stage, (2) Applying traditional games stage in three activities (opening, main activity and closing), and (3) Evaluating stage. The result from pre-test and post-test can be concluded that the result of traditional games in developing honesty character for young learners at TK Pancasila Journal Indonesian Language was the changing of individual character shown from the increase of honesty character quality as the effect of learning process from experience in playing traditional games. Was the changing of individual character shown from the increase of honesty character quality as the effect of learning process from experience in playing traditional games. The supporting factors of 
applying traditional games at TK Pancasila included: (1) Structured curriculum, (2) Fairly high playing motivation from young learners, (3) Conducive facilities and environment to support the process of applying traditional games. The obstructing factors included: (1) The unstable young learners concentration, (2) The minimum time used for traditional games activity, (3) Limited knowledge from teachers about kinds of traditional games used in teaching especially to improve honesty character development from young learners.

Jo Basford \& Caroline Bath "Playing the assessment game: an English early childhood education perspective" [4] Assessment and the documentation of learning is an international issue in early childhood education (ECE) and has increasingly become a way for governments to exercise direct control over the practitioners working with young children. This paper details recent statutory guidance about assessment and documentation for English ECE settings and deconstructs the latest English ECE policies, highlighting that these often give contradictory messages to practitioners. It suggests that practitioners are caught up in playing a game: trying to make compatible assessment practices that address both the scientific discourse of empiricism and a more recent internationally influenced sociocultural discourse, as outlined by soler and Miler. However, we concede that it is unrealistic to reproduce practices that have deeply culturally embedded significance elsewhere. The paper therefore outlines key challenges for English practitioners: how to use documentation as a generative assessment tool and how to make assessment more collaborative. We suggest that addressing these issues through building pedagogical knowledge could enable practitioners to develop greater confidence when playing the assessment game.

\section{METHODS}

The methodology being used in this research is literature review according to Nazir in Eureka Pustaka Library literature or study literature. A part from looking for secondary data source that will support the research, it is also needed to know where the knowledge up to in relation with the research has been growing, until where the conclusion and generation has been made so we got the situation needed.

\section{FINDING AND DISCUSSION}

Playing is one of the world's most exciting child activity. Many experts define play. Stone [5] states that play is real. It is Vital. Play helps children learn about their world naturally. Hurlock [6] states that play is any activity done for the pleasure without considering the final result. According to Cosby S. Roger and Janet K. Sawyers [7], playing for child is a desirable activity, due to by playing, the child will feel free and fun. Playing activities performed by the child will raise the intrinsic motivation, provide peace and provide life balance for the child. Docket \& Fleer [8] expresses that play is a necessity for children because through playing the child will gain knowledge that can develop their ability. Vygotsky (Naughton, 2003) says that play can create a proximal development zone in children. Based on the explanation of the experts above it can be described that understanding play is a fun activity for children because children feel free, giving peace to gain knowledge and can create a zone of proximal development in children.

Benefits of playing by Spodek \& Sarcho [Montolalu et al, 9] in a safe and playful play environment, spurring children to discover ideas and using their imaginative power. Research results support the notion that play and creativity are related because both play and creativity rely on a child's ability to use symbols -simbol.In the play activities of many games that can develop the developmental function of the child. Piaget game function [Santrock, 10] game as a medium that enhances the cognitive development of children. Daniel Berlyne [santrock, 10] game as fun and fun because it satisfies our exploratory drive. A supportive environment can create an atmosphere of learning through fun play for young children, a conducive environment according to Mulyasa [11], among others, creating mutual respect among children, as well as between children with teachers and other education personnel. It is important that every child has the widest possible opportunity to express his views without fear of getting sanctioned or humiliated.

Based on the explanation of the experts above, it can be described that the learning activity in early childhood is done with play approach which can stimulate the developmental dimension of the child either cognitive, language, social emotion, motoric physic and other development, but in reality there are many institutions of Early Childhood Education Still stuck with the activities of literacy reading or better known as "calistung" learning in the box like primary school. Based on the above problem, the 
writer tries to describe Application of 'say yes or no' Game in Instilling Character Education

The cultivation of education in early childhood especially in the cultivation of the education of character is very important, Lickona (1991) character related to moral concept, moral attitude and moral behavior and according to Tilman and Hsu [12] (Living value) is very important to be developed, not only included in the field of development of customs through habituation, but must be integrated with all areas of development, including through situations in school institutions built on these values. In early childhood if stimulated children will respond quickly because the child is a great imitator for it needs a model that can shape the child's character well, the role of parents, teachers, adults around the child is very important in shaping the character of the child.

Application of 'say yes or no' Game in Instilling Character Education a play activity expected to instill character education and children dare to express their feelings honestly and can stimulate other child development dimensions such as moral religion value, cognitive development, language development, physical development Motor, social development of emotions, the development of art and other developments.

In this game the child is faced with five cards, namely: 1) the picture content of the message the child can "share food" with a picture card food 2) the second picture of the message the child would "take turns playing toys" with a picture card toy 3) the third picture befriended the message " Playing together "with a picture card playing together, 4) a picture of" helping a friend "with a child's picture card helping a friend and 5) drawing the fifth" mutual love "with a child's picture card hand in hand.

How to play done individually by teacher to start the Application of 'say yes or no' Game in Instilling Character Education, the teacher is trying to create a fun game atmosphere so that children feel comfortable, the child just answer yes or no with the question Asked the teacher and the child to give a reason, in this case there is no intervention from the teacher teach children to express feelings honestly. For example when the child responds: 1) the picture card of a child's "food share" responds "no" the reason I like my food; 2) the picture cards are two "alternately playing toys" the child responds "no", the reason I like this toy, 3) the card The picture of the three "playing together" the child responds "yes", the reason I like to play together, 4) the four picture cards "help friends", the child responds "yes" the reason I like the friend, 5) the five picture cards "love each other" , The child responds "yes" the reason dear friend.

But the fact is not infrequently children who do not dare to reveal honestly many children choose to be silent, the role of teachers give comfort to children and believe the child but not force the child if the child does not dare to reveal the extension to force the child because the purpose of this game children feel comfortable and dare to express honestly Without any intervention. When the child has finished playing this game and dare to honestly disclose the role of individual teachers to the children provide appropriate inputs to develop character education of the child by paying attention to the child's feelings of the conditions and situations experienced by children so that children feel comfortable and do not feel blamed, then done Together with the other child. The goal of the child is given the input individually to maintain the sense of security of children and children are not humiliated in front of other friends.

\section{CONCLUSIONS}

Vygotsky (Naughton, 2003) play can create a zone of proximal development in children. Piaget game function [10] game as a medium that enhances the cognitive development of children. In early childhood if stimulated children will respond quickly because the child is a great imitator for it needs a model that can shape the child's character well, the role of parents, teachers, adults around the child is very important in shaping the character of children. One of the activities of the Application of 'say yes or no' Game in Instilling Character Education is a play activity that is expected to instil character education and children dare to express their feelings honestly and can stimulate other child development dimensions such as moral religion value, cognitive development, language development, Physical motor development, social development of emotions, art development and other developments.

\section{REFERENCES}

[1] Patmonodewo, Pendidikan Anak Prasekolah. Jakarta :Rieneka Cipta, 2003

[2] Khristianto, The Child goes green via Traditional Games (A part of Early-Childhood Character Building) Proceeding, Yogyakarta State University, 2010 
[3] Wulandari Rifa Suci \& Hestri Hurustyanti Journal Indonesian Language Education and Literature Vol. 2, No. 1, 2016

[4] Basford Jo \& Caroline Bath, Journal Early Years An International Research Journal vol 34 2014

[5] Stone, Sandra J. Playing A kid's Curriculum Scoot t Foresman Glenview, Goodyear : Books , 1998

[6] Hurlock, ELizabeth. B.,. Perkembangan Anak, Penerbit Erlangga : Jakarta, 1999

[7] Roger, Cosby S. and Janet K Sawyers. Play in the Lives of Children, (washingtton DC : Nasional Association For Young Children, 1995

[8] Docket, Sue \&Marlyn Fleer. Play and Pedagogy in Early Childhood-Bending the Rules, Sidney : Harcourt, 2000

[9] Montolalu BEF. Bermain dan Permainan. Jakarta :Universitas Terbuka, 2012

[10] Santrock, W John, Life Span Development, Perkembangan Masa Hidup, Jakarta :Erlangga, 2002

[11]Mulyasa, H.E, Manajemen PAUD, Bandung : PT Remaja Rosda Karya, 2011

[12] Tillman, Diane dan Diana Hsu, Living Values : An Educational Program, Living Values Activities for Children Ages 3-7, Jakarta : Grasindo, 2004 